\title{
'SHOW ME YOUR HORSE AND I WILL TELL YOU WHO YOU ARE': BREXIT, A CHANCE TO ACKNOWLEDGE ANIMAL SENTIENCE IN LAW
}

\author{
Jessica Horton* $\quad$ Jonathan Merritt**
}

\section{INTRODUCTION}

This article is written to explore the current position of the concept of animal sentience in UK animal welfare law. This is based on research carried out since 2017 but there have been political and legal developments which bring the issue to the fore now, chiefly these are concerned with Brexit and the EU definition of animal sentience contained in the Lisbon Treaty.

At time of writing, there could scarcely be less certainty about the likely final outcome of the United Kingdom's endeavours to exit the European Union. The United Kingdom became a member state in 1973 by virtue of the European Communities Act 1972 and it is essentially this legislation that is being repealed as part of the process of leaving. The primary legislation of the European Union has evolved since the Treaty of Rome 1957 which the United Kingdom became a signatory to. That legislation is now in the form of the Treaty on the Functioning of the European Union (TFEU) and it is Article 50 of this treaty that was triggered by Theresa May's Conservative administration as a result of the second referendum held in 2016, the first, in which 'remain' won, was held in 1975. Prime Minister May's Government set the date of leaving as $29^{\text {th }}$ March 2019. However, the House of Commons could not reach agreement on multiple occasions over the withdrawal agreement struck by May with the EU. More energetic debate took place in the days leading up to Thursday $14^{\text {th }}$ March 2019 when the Commons voted to ask for a delay to the leaving date. May then secured a delay until $31^{\text {st }}$ October 2019, ultimately resigning on $7^{\text {th }}$ June as she could make no further progress persuading Parliament to accept her deal. A leadership contest is underway at the time of writing with Boris Johnson MP the favourite

\footnotetext{
PhD candidate at Northumbria University, First Class Honours graduate and 2017 Evenden Prize Winner at De Montfort University, Department of Law.

** Research Co-Ordinator, Centre of Research and Innovation for Sport, Technology and Law (CRISTAL) and Senior Lecturer in Sports Law, specialising in equine sports law, De Montfort University, Department of Law.
} 
to win. Johnson has made it clear he intends to leave the EU at the end of October with or without a deal in place. If Parliament will not agree to allow a new Prime Minister Johnson to take the United Kingdom out of the EU without a deal, a general election is a possibility as is not leaving at all if a much-discussed third referendum does take place thereafter.

Consequent on all this, it is difficult at present to find many people, either on the 'leave' or 'remain' side of the argument, with positive views about how Brexit has been managed thus far, or the politicians involved in its progress. This paper does however discuss a glimmer of hope from this apparent chaos, not for the human population necessarily but for the fauna of these isles, not least among those, and given the focus of this article, the equine population. That is to say whatever view is taken of Brexit, it has at least brought to the fore the definition of animal sentience as enshrined in English law for reconsideration.

\section{THE REPEAL OF THE SENTIENCE DEFINITION}

In order to explore fully the place of animal sentience in UK animal welfare law, it will be necessary to consider the fate of the EU definition of sentience. As a precursor to the current Parliamentary process, the 'Great Repeal Bill' made its way through the House of Commons, designed to bring many existing EU provisions into UK law at the point of the country's departure from the EU. There were a great many amendments debated, including 15 where the Government lost on their wording in the House of Lords and 170 further changes that were proposed by that Upper House during the so-called 'ping-pong' stage, where the text passes between the Houses repeatedly. ${ }^{1}$ In total, Parliament spent an estimated 272 hours debating the Bill. ${ }^{2}$ This is unprecedented and reflective of the deep divisions within the political parties and indeed the country, as to what the future relationship with the EU should be. At the time of those debates, a 'Hard Brexit', with no agreement, a reversion to World Trade Organisation (WTO) trade tariffs and an abrupt departure from all EU institutions and treaties looked more likely than it does now; but as this article is being finalised, the situation is changing almost hourly.

One of the votes mentioned above produced an extreme media and social media reaction on its own; however, this was the vote effectively to repeal the concept of 'animal sentience' as it currently exists in EU law. The Great Repeal

\footnotetext{
1 'EU Withdrawal Bill: Amendments and Debates' (Institute for Government, 2018) $<w w w . i n s t i t u t e f o r g o v e r n m e n t . o r g . u k / e x p l a i n e r s / e u-w i t h d r a w a l-b i l l-a m e n d m e n t s-a n d-$ debates> accessed 18 March 2019

2 Ibid.
} 


\section{THE DENNING LAW JOURNAL}

Bill did not have a provision to include the following provision in UK law at all. It is currently found in the TFEU or 'Lisbon Treaty':

In formulating and implementing the Union's agriculture, fisheries, transport, internal market, research and technological development and space policies, the Union and the Member States shall, since animals are sentient beings, pay full regard to the welfare requirements of animals, while respecting the legislative or administrative provisions and customs of the EU countries relating in particular to religious rites, cultural traditions and regional heritage. ${ }^{3}$

During the Committee Stage of the Bill there had been unsuccessful attempts to include the principle in UK law as it stood, but without Government support these failed. The administration's response was that it wanted to 'consider how it might explicitly reflect the sentience principle in wider UK legislation'. ${ }^{4}$ This raised the concern, voiced in the press and social media predominantly, that the vote against was a signal that Parliament was not prepared to recognise the concept of animal sentience at all, or at least sufficiently, after March 2019. Ministerial Guidance was issued within days which attempted to refute his position. Specifically, it stated that ' $[\mathrm{t}]$ he vote ... was the rejection of a faulty amendment, which would not have achieved its stated aims of providing appropriate protection for animals [and that the].... Prime Minister has made clear that we will strengthen our animal welfare rules'. 5 The alacrity with which this document appeared was perhaps a sign that the Government was very much alive to the likely public backlash from a population that thinks of itself as a 'nation of animal lovers'. This would not be welcome on top of internal and international widespread concern that the Brexit process, whatever the merits of the vote in June 2016, has since then been characterised by seeming ineptitude and confusion on the UK side. ${ }^{6}$ This

3 Article 13 of Title II, Lisbon Treaty, which came into force in 2009.

4 House of Commons Briefing Paper Number 8155, 'Animal Sentience and Brexit' (Parliament, 8 August 2018) <https://researchbriefings.files.parliament.uk/documents/ CBP-8155/CBP-8155.pdf $>$ accessed 18 March 2019.

5 Michael Gove, MP, 'Animal Welfare: Written Statement - HCWS267' (DEFRA, 23 November 2017) <https://www.parliament.uk/business/publications/written-questionsanswers-statements/written-statement/Commons/2017-11-23/HCWS267> accessed 18 March 2019.

${ }^{6}$ Frances Perraudin, 'Brexit Vote Is Making UK a Laughing Stock Abroad, Says Tim Farron' (The Guardian Online, 31 August 2016) <https://www.theguardian.com/ politics/2016/aug/31/brexit-vote-nigel-farage-making-uk-laughing-stock-abroad-timfarron> accessed 18 March 2019; 'FTSE 100 Down as Investors Shun "Laughing Stock" 
prompted Michael Gove, Environment Secretary and prominent Euro-sceptic, to appear on national radio to further emphasise the Government's commitment to animal welfare and also to make the wider point that there is, in the Government's view, an erroneous widespread assumption that Parliament cannot do better than the EU on a host of issues, from worker's rights to environmental protection and in this case the maintenance of animal welfare. ${ }^{7} \mathrm{He}$ urged the people to 'trust' the domestic democratic process to surpass the standards that the EU has mandated in this sector.

As a first step a draft Animal Welfare (Sentencing and Recognition of Sentience) Bill 2017 was produced and consulted on between December 2017 and January 2018. A short period given the intervening Christmas period when minds are not necessarily wholly focussed on draft legislation. Nevertheless, the Department for Environment, Food and Rural Affairs (DEFRA) has responded to the consultation and made some changes to the Bill consequent on that. ${ }^{8}$ Chiefly those are around sentience being fully recognised in the new law and longer potential sentences. These proposals will be discussed further below.

\section{'THE BEST WAY TO FIND OUT IF YOU CAN TRUST SOMEBODY IS TO TRUST THEM'}

If the Environment Secretary wishes voters to believe that animal sentience will be fully enshrined in post Brexit UK statutes, then a full analysis of UK law to date will be needed. Ernest Hemingway's quote has much to commend it but an alternative, if less poetic, approach, at least where politics and law making are concerned, is to research past performance to establish whether the trust Mr Gove wishes to rely on in this specific context, is warranted. A study was already underway at De Montfort University (DMU) into the very point Gove touched on, the

UK after Theresa May's Brexit Deal Defeat' (SkyNews Online, 16 January 2019) <https:// news.sky.com/story/ftse-100-down-as-investors-avoid-the-uk-after-theresa-mays-brexitdeal-defeat-11608654> accessed 18 March 2019; “"A Complete Humiliation”, a "Crushing Defeat" and Brextinction: Global Media Reacts to Brexit Vote' (CNBC News Online, 16 January 2019) <https://www.cnbc.com/2019/01/16/global-media-reaction-to-theresa-maybrexit-vote.html> accessed 18 March 2019.

7 Michael Gove MP, speaking to John Humphries on 'The Today Programme' of 24 November (BBC Radio 4, 2017).

8 DEFRA, 'Response to Consultation of the Draft Animal Welfare (Sentencing and Recognition of Sentience) Bill 2017' (DEFRA, 2018) <https://www.gov.uk/government/ consultations/draft-animal-welfare-sentencing-and-recognition-of-sentience-bill-2017> accessed 22 March 2019. 
extent to which, if at all, the UK legal landscape recognises the emerging and accelerating understanding of animals as sentient beings. Events in Parliament currently unfolding throw into sharp relief what has always been true in a democracy, the draft of a Bill may bear almost no relation to the act which is eventually presented for Royal Assent, so the production of such draft legislation specifically on animal sentience does not negate the need for this paper. It merely provides a further line of enquiry. All of this does mean however that this is an auspicious time to be writing about the findings of the socio-legal and doctrinal research in the DMU study. This paper sifts that research and analyses the extent to which UK law to date has kept up with animal welfare concerns to date, in an effort to weigh the current Government's assertion in the balance. Can the Parliament really lead the way in protecting animals as sentient beings, based on past performance? Further, if there is a problem, is it limited to the legislature?

\section{NARROWING THE SCOPE OF THE STUDY}

The DMU study began from the premise that from an eco-centric or bio-centric point of view, ${ }^{9}$ society owes a moral, indeed, a practical obligation to uphold the principle of animal welfare and this is especially apparent when considering the position of domestic animals. This does not dismiss that there are those who espouse the anthropocentric, mainly biblically derived, view that animals are here to serve us, and their needs are wholly secondary to those of God and humankind. ${ }^{10}$ However, to consider that viewpoint as equal would require a discourse as to whether animal welfare needs to be considered at all and that is outside the scope of this paper.

While many people have the humanity to be kind, considerate and sensible towards animals, there are others who do not, and even among animal lovers there is inconsistency as to what constitutes appropriate behaviour towards other creatures. A vegetarian, a vegan and a meat lover might each claim to be in favour of high standards of animal welfare for instance, yet vehemently disagree on the degree to which animal produce might rightly be consumed by humans. This is why animal welfare law needs to be clear, consistent and enforceable to maintain a humane yet pragmatic level of protection to animals. This legislation will always have to steer a middle course and will be unlikely to be acceptable to all. However, this paper argues that there is currently no such consistency and clarity in the law,

9 For an explanation of how these concepts impact on law making and law breaking, see Tim Newburn, Criminology ( $2^{\text {nd }}$ edn, Routledge 2007) 903-904.

10 See, for instance, Psalm 8:6-8 NIV. 
as written, or perhaps more crucially, as applied. The proposed legislation is now put under a similar scrutiny as well.

A wider study could have taken into account wild animal welfare issues like hunting controversies, the farming industry, conservation, zoos, scientific experimentation and so on, but this research was limited to domesticated animals for reasons of manageable scope. These animals have a largely predetermined destiny before they are born, especially those that are in the food chain like hens, cattle and pigs. In the twenty-first-century UK the population is overwhelmingly two or more 'generations away from the land' and thus views nature and the animal kingdom in an increasingly abstract way having had little contact with real flora and fauna.$^{11}$ This is compared to a much greater proportion of the population who in our agrarian past would have had to directly work the land. This can lead to a disconnect between the animal seen in image form or described in words and the reality of the constituent parts of that animal found in a packet of frozen sausages or in a bucket of fried chicken. The term 'Nature Deficit Disorder'"12 has been coined to describe the negative effects of an increasingly urbanised, mechanised and cyber-based life. The animals we have the most contact with are domesticated, tame and mostly kept as pets.

For Stibbe, society distances itself from what is reality through its choice of language. Humans are murdered; animals on the other hand are slaughtered. When, therefore, the term slaughtered is used referring to humans, it is intended to underpin the abhorrent and immoral nature of the action when applied to humans. A further example is the terms used to describe meat in terms other than those directly identifying the animal, poultry rather than chicken, beef rather than cow for example. This distances the individual from what is reality. ${ }^{13}$ 'How animals are socially constructed influences how they are treated by human society ... [c]ultural constructs determine the fate of animals'. ${ }^{14}$ These cultural constructs are in turn 'intimately bound up with language and discourse'. ${ }^{15}$ It is true therefore to say that this places the law in a difficult position, to enact new laws or amend existing ones there needs to at least an indication that a clear majority agreement that change is

11 Richard Louv, Last Child in the Woods: Saving Our Children from Nature-Deficit Disorder (Algonquin Books 2005) 34. See also Stephen Moss, Natural Childhood Report (National Trust 2011).

12 Ibid.

13 Arran Stibbe, 'Language, Power and the Social Construction of Animals' (2001) 9(2)

Society \& Animals <https://www.animalsandsociety.org/wp-content/uploads/2015/11/ stibbe.pdf > accessed 27 March 2017.

14 Ibid.

15 Ibid. 
necessary. This sometimes occurs through the development of societal values in a much wider way, such as the now more common broader acceptance of same-sex relationships. Sometimes a degree of subtle 'engineering', backed up by incremental changes in the law is necessary, the increasing social stigma attached to speeding and drink-driving and also smoking are examples of this. Such a careful yet effective media and legislative programme as that which now restricts nicotine consumption has been far more productive than an outright ban would have been. It is therefore possible to similarly raise the perception of animals as sentient among a broader cross-section of the public and thus give further momentum to the changing social construction described above.

There is no longer the need for each of us to capture and slaughter our own animals as they are already there in excess on supermarket shelves. Paradoxically, our consumerism has had a huge detrimental impact on animals; our demand for cosmetics, furs, and entertainment has led to their abuse and to extinctions at an alarming rate; this is aided and abetted by the increasing tendency to view meat and animal products in abstract terms as discussed earlier. There is a growing reaction to this trajectory however and animals, particularly those domesticated, such as the horse, are no longer viewed as simply property owing to these changing social constructions. It may be fanciful to say there will be a day when society will look back and be dismayed at how we treated our animals now. Still further that society may be unable to fathom that animals were viewed and kept as property. Having said that, slavery and child labour were once social norms and are no longer considered acceptable and so there is a precedent for such a renewal.

\section{SOCIAL CONSTRUCTIONISM JUSTIFYING EQUINES AS A RESEARCH FOCUS}

Considering that dogs are a so-called '(wo)man's best friend', this might justify concentrating on domesticated canines for this study and 'archaeological evidence indicates that the dog was the first species of animal to be domesticated towards the end of the last Ice Age. ${ }^{16}$ This paper does draw analogies from time to time with other domesticated species, such as with dogs, as appropriate too but the richer vein to be mined however was the wealth of social scientific evidence illuminating the unparalleled relationship between Homo Sapiens and Equus Ferus Caballus. This is characterised by its longevity, cultural and social importance and enduring nature. At the heart of humankind's unique relationship with many animals is centuries of domestication. In relation to equines, 'research indicates

16 James Serpell, The Domestic Dog, Its Evolution, Behavior and Interactions with People (CUP 2002) 10. 
that horses were first domesticated by the Botai Culture of Kazakhstan around 6000-5500 BC' ${ }^{17}$ The earliest horse remains were discovered in Suffolk and Sussex dating 700,000 BC and 500,000 BC, respectively. ${ }^{18}$ During these millennia, the horse as a social construct evolved and is still an evolving phenomenon. Horses are no longer a source of industrial or agricultural power although even here their influence lingers on. James Watt based his now commonplace measurement of power on the workhorse of the day as one 'horsepower' (HP) is the power required to lift 33,000 pounds by one foot in one minute'.$^{19}$ Equines do however occupy a special place in our collective psyche still. For social scientists, the horse, especially the elite competition animal, can even be categorised now as an 'athlete'. Gilbert, ${ }^{20}$ among others, has explored the social processes that have reclassified horses as athletes in equestrian sport. ${ }^{21}$ In this case exploring the sport pony as an athlete, based on work by Latimer and Birke ${ }^{22}$ It is not just changing the uses of the horse but also specific breeding practices that generate meanings around the identity of a specific type of horse. These changing uses are key though in that humans are now presented with the horse in art, culture and sport rather more than on the roads or in the fields working the land. These changing uses are in turn shaped by 'evolving social structures', ${ }^{23}$ much as other developing technology of all kinds tends to lead to change in human social interaction, take the Internet and the smartphone as examples which have utterly transformed the ways that humans communicate and socialise.

The language of horses qua athletes is now even prevalent in sporting regulations such as those of the Fédération Equestre Internationale (FEI) and in Court of Arbitration for Sport (CAS) arbitral awards in disputes over those regulatory provisions. A large swathe of these are animal welfare stipulations rather than 'rules of the game' and as an example, in one such case the court stated

17 'Domestication History of Horses' (Equine World UK, n.d.) <http://www.equineworld. co.uk/about-horses/domestication-history-of-horses> accessed 20 July 2017.

18 David Smith, Only Horses from Wild (Lulu Press 2016) 7.

19 Ben Johnson, 'The History of Horses in Britain' (Historic UK, n.d.) <http://www. historic-uk.com/CultureUK/The-History-of-Horses-in-Britain> accessed 13 July 2017.

20 Michelle Gilbert and James Gillett, 'Equine Athletes and Interspecies Sport' (2012) 47(5) International Review for the Sociology of Sport, 634-635.

21 Jonathan Merritt, “Don't Look a Gift Horse in the Mouth" - Regulating for Integrity, What Equestrianism Can Learn from Thoroughbred Racing' (2017) 16(3) International Sports Law Journal, 202.

22 Joanna Latimer and Linda Birke, 'Natural Relations: Horses, Knowledge, Technology' (2009) 57(1) The Sociological Review, 1-27.

23 Ibid., 8. 
that ... '[a] central and distinctive feature of equestrian sport is that it involves a partnership between two types of athlete, one human and one equine'. ${ }^{24}$

Animal welfare law is quintessentially about the relationship between humans and animals and the regulation of that interaction by the state. Using predominantly the horse as the basis of the study makes sense because of just how nuanced the relationship between the species of human and horse actually is. The importance of the changes in the social construction of the horse cannot therefore be overstated for the propositions in this paper. The process of assimilating the horse into modern popular culture has involved a degree of anthropomorphosis and this extends down from the competition horse to the leisure animal. For example, cartoonists like Norman Thelwell ${ }^{25}$ have given the pony human expressions, found in many children's books and on numerous greeting cards. Likewise, animated horse characters in film and television routinely speak and express feelings. In keeping with this process, the equine characters' faces are often drawn with distinctly human features. For instance, those horse characters found in animated films such as 'One Hundred and One Dalmatians', ${ }^{26}$ 'Sleeping Beauty' ${ }^{27}$ and 'Tangled'28 are drawn with human eyes to the front of the face to enable human expressions and mannerisms to be exhibited. This process is a fundamental yet very subtle, influence on the way children socially construct the horse, this will very likely continue into adulthood as learned behaviour, further cementing the horse's almost quasi-human place in culture.

We have enormous interaction with marketing campaigns as adults as well. The Budweiser Clydesdales are not unknown in the United Kingdom, but their media presence is undoubtedly greater in the United States where they are considered an 'American Icon'. ${ }^{29}$ The Lloyds Bank black horse is a familiar UK

24 CAS 2012/A/2807 Khaled Abdullaziz Al Eid v Fédération Equestre Internationalel CAS 2012/A/2808 Abdullah Waleed Sharbatly v Fédération Equestre Internationale [6.24].

25 Norman Thelwell, b. 1923, d. 2004, illustrated and/or wrote around 40 titles, many featuring an overweight and recalcitrant pony and its frustrated or despairing young female rider, both being effectively human caricatures.

26 One Hundred and One Dalmatians (1961) Directed by Clyde Geronimi, Hamilton Luske and Wolfgang Reitherman [Film] USA: Disney Pictures Corporation.

27 Sleeping Beauty (1959) Directed by Clyde Geronimi, Les Clarke, Eric Larson and Wolfgang Reitherman [Film] USA: Disney Pictures Corporation.

28 Tangled (2010) Directed by Nathan Greno and Byron Howard [Film] USA: Disney Pictures Corporation.

29 See Budweiser.com <http://www.budweiser.com/clydesdales/history.html> accessed 25 July 2017. Some of the 250 Budweiser Clydesdales have pulled drays in two Presidential Inauguration celebrations. 
High Street sight, however. The bank's television advertisements from as early as 1988 featured a Trakehner stallion called Downlands Cancara filmed galloping at full speed across grassland before rearing and morphing into the familiar graphic logo. ${ }^{30}$ By 2015, the 250-year anniversary television campaign was featuring a range of black horses with actors in historical costume fighting fires, waging wars, ploughing fields, delivering milk and ultimately delivering therapy to a disabled rider. The company sought to draw parallels between the loyalty and importance of the horse to society and the same qualities displayed by the bank since its incorporation. ${ }^{31}$ Budweiser wishes to associate the qualities of the Clydesdale with its corporate values too.

Equines are in a slightly different position than other domesticated animals admittedly, not truly occupying the position of domesticated 'pet' and not being in the food chain by and large either. Like farm animals, dependence on humans has become almost total and having been domesticated, the horse is dependent on nutrition and care provided by man. The horse requires large quantities of poorquality forage which is quite different from the lush sugary pasture that many modern horses have access to in the United Kingdom, Northern Europe and modern North America. ${ }^{32}$ To avoid conditions like Laminitis and Equine Metabolic Syndrome, careful husbandry is required to the extent that the notion that a horse can simply be left to graze almost anywhere is quite misplaced. ${ }^{33}$ To some extent then, the relationship between humankind and horse has, from the point the horse first became a beast of burden, through to the mid-twentieth century at least, begun to approach the symbiotic. This is quite different from the hunter-prey correlation of prehistory. The horse has therefore been for some centuries reliant on man for its survival as a species and in turn has been pivotal in the development of humankind's warfare, agriculture, industry, commerce and culture. ${ }^{34}$ This somewhat unique position in the animal kingdom presents us with our best candidate for a single species to provide a focus to consider the legal concept of animal sentience.

30 Trademark UK00002563746.

31 Lucy Elder, 'Black Horse Returns to Lloyds Bank Advertising Campaign' (Horse and Hound Online, 29 June 2015) <http://www.horseandhound.co.uk/news/lloyds-bank-blackhorse-250-anniversary-advertising-campaign-500348> accessed 7 July 2019.

32 See, for instance, 'Starch, Sugar and Fructans: What Are They and How Important Are They in Diets for Horses?' In 'The Latest Findings in Laminitis Research' (2007), (The $1^{\text {st }}$ Waltham - Royal Veterinary College Laminitis Conference).

33 Ibid.

${ }^{34}$ Merritt (n 23) 201-202. 


\section{WHAT DO WE MEAN BY 'ANIMAL SENTIENCE’?}

To consider whether animal sentience is, or could be, adequately acknowledged in UK legislation, some clarity will be needed about the term. Sentience is now widely recognised ${ }^{35}$ as being applicable to animals but what is it? This acknowledgement illustrates a change in our understanding, perhaps animals possess more similarities to humans than was previously thought. Research has provided strong evidence that animals have subjective experiences, and that they can feel and/or perceive. In 2012, a number of prominent scientists gathered at the University of Cambridge to sign the 'Cambridge Declaration on Consciousness'. ${ }^{36}$ Part of the declaration reads as follows:

...consequently, the weight of evidence indicates that humans are not unique in possessing the neurological substrates that generate consciousness. Non-human animals, including all mammals and birds, and many other creatures, including octopuses, also possess these neurological substrates. ${ }^{37}$

The signing of the declaration is a clear indication that our previous conception of an animal's cognitive ability is changing. In terms of horses, there have been a number of studies by researchers in human psychology ${ }^{38}$ into equine cognition. For instance, such as Proops and McComb have established that 'cross modal' individual recognition (using two or more senses interacting with each other) is not just a human only trait as previously believed. The researchers chose horses instead of other animals because of the unique relationship they have with our species, also rather underscoring the conclusions reached in the last section of this paper. They stated that '... the domestic horse is an ideal animal model for this

${ }^{35}$ Marc Bekoff, 'After 2,500 Studies It's Time to Declare Animal Sentience Proven' (Op-Ed), (Live Science, 6 September 2013) <http://www.livescience.com/39481-time-todeclare-animal-sentience.html> accessed 10 April 2017.

${ }^{36}$ Philip Low and others Koch (eds), The Cambridge Declaration on Consciousness (2012) <http://fcmconference.org/img/CambridgeDeclarationOnConsciousness.pdf > accessed 10 April 2017.

37 Ibid.

${ }^{38}$ See, for example, Jessica Lampe and Jeffrey Andre, 'Cross-Modal Recognition of Human Individuals in Domestic Horses (Equus Caballus)' (July 2012) 15(4) Anim Cogn, 623-630; Konstanze Krueger and others, 'Horses (Equus Caballus) Use Human Local Enhancement Cues and Adjust to Human Attention'(March 2011) 14(2) Anim Cogn, 187201; Yuki Henselek, Julia Fischer, Christian Schloegl, 'Does the Stimulus Type Influence Horses' Performance in a Quantity Discrimination Task?' (2012) Front Psychol 3, 504. 
research because it has a complex social organisation and close relationship to man, making individual recognition of humans a highly functional ability' ${ }^{39}$ Certain jurisdictions are now beginning to explicitly use the term 'sentience' in their legislation; Australasia and Canada are two examples. In England and Wales, there is welfare legislation in place that covers domesticated animals, but it is the current absence of explicit and clear recognition of animal sentience which brings into question whether the law effectively reflects this new hegemony and provides appropriate safeguards. This in turn does not tend to support Michael Gove's exhortation to trust lawmakers to protect animal welfare adequately post-Brexit. It is true that a draft Bill on this very issue has been quickly published and consulted on, but it is important to be cautious about whether this will result in anything meaningful changing in relation to animal sentience as enshrined in the law.

There follows an analysis of the main antecedents and drivers for the enactment of the Animal Welfare Act 2006 (AWA), and whether, 11 years on from its original enactment, it is proving to be an effective piece of legislation given the foregoing points.

\section{HISTORICAL DEVELOPMENT OF UK ANIMAL WELFARE LAW}

The current appreciation of animal sentience in this area, such as it is, has been long in the making. In 1635, Ireland gave rise to the first animal welfare legislation, the Act against Plowing by the Tayle. ${ }^{40}$ All of Ireland was under British rule at the time and this is the first piece of domestic legislative protection for animals documented. The next significant change occurred in 1822, when Richard Martin MP successfully proposed the first more general piece of animal welfare legislation, an Act to Prevent the Cruel and Improper Treatment of Cattle. ${ }^{41}$ Subsequently in 1824, the first animal welfare charity, the Society for the Prevention of Cruelty

39 Leanne Proops and Karen McComb, 'Cross-Modal Individual Recognition in Domestic Horses (Equus Caballus) Extends to Familiar Humans' (2012) Proceedings of the Royal Society B, vol. 279 (1741), 3131.

40 Jennifer Maher, Harriet Pierpoint and Piers Beirne (eds), The Palgrave International Handbook of Animal Abuse Studies (Springer 2017) 2. Thanks are also due to Dr Clare Leon Department of Sociology, University College Cork, Eire for her paper 'Horses and the Law - A Comparative Perspective' at the 'Horses, Society and the Law: Past, Present and Future' Conference, $11^{\text {th }}$ April 2017, De Montfort University, Leicester, UK, which provided the stimulus for this part of the research.

41 'Animal Welfare' (Politics.co.uk, n.d.) < http://www.politics.co.uk/reference/animalwelfare> accessed 31 August 2016. 
to Animals, was established, later becoming the Royal Society for the Prevention of Cruelty to Animals (RSPCA) in $1840 .{ }^{42}$ Other legislative advances emerged during the nineteenth century such as the Pease's Act 1835. The Act not only consolidated the legislation passed in 1822 but, inter alia, 'the prohibition of cruelty was extended to dogs and other domestic animals, bear-baiting and cock-fighting was forbidden, and it insisted on better standards for slaughter-houses, ${ }^{43}$

Since then there have been a number of statutes such as the Cruelty to Animals Act 1849 and 1876 and the Protection of Animals Act 1911 (PAA). The latter was 'an Act to consolidate, amend, and extend certain enactments relating to Animals and to Knackers; and to make further provision with respect thereto. ${ }^{44}$ Commentators consider that ' $[\mathrm{t}] \mathrm{he} 1911$ Act marks the beginning of contemporary legal attitudes to animals ${ }^{25}$ as it combined recent developments and specifically made certain acts against animals, offences of 'cruelty'. This is important for this paper because synonyms for 'cruel' include 'inhuman', 'wicked', 'evil' and 'spiteful' among many other similar terms. It goes without saying that it is not possible to be these things towards something that cannot feel or perceive. One can be cruel to a hamster but even in our enlightened age, not to bacteria or tapeworm for example. Under the Act it was an offence to:

...cruelly beat, kick, ill-treat, over-ride, over-drive, over-load, torture, infuriate, or terrify any animal, or...cause any unnecessary suffering, or, being the owner, permit any unnecessary suffering to be so caused to any animal. ${ }^{46}$

Prison and fines were included as sanctions in this legislation as well. ${ }^{47}$ The PAA was an advancement in that it combined existing legislative provisions from the previous century, updated them and formed a single piece of legislation that covered domesticated and captive animals. Nevertheless, for Radford, the '... 1911 Act is something of a dichotomy. On the one hand, it represents continuity ... on the other, it can be seen as a break with what had gone before ... ${ }^{48}$ This is because

42 'Our History' (RSPCA, n.d.) <https://www.rspca.org.uk/utilities/aboutus/history> accessed 31 August 2016.

43 Ibid.

44 Protection of Animals Act 1911, Long Title.

45 Simon Brooman and Deborah Legge, Law Relating to Animals (Cavendish 1997) 50.

46 Protection of Animals Act 1911, s 1.

47 Ibid.

48 Mike Radford, Animal Welfare Law in Britain Regulation and Responsibility (OUP 2001) 88 . 
well-organised lobbying since 1822 had steadily increased the protection from the law afforded to animals. Animal welfare law continued to be developed throughout the twentieth century, with the introduction of further legislation such as the Pet Animals Act 1951, Riding Establishment Acts 1964 and 1970 and the Welfare of Animals at Slaughter Act 1991. However, the most significant piece of legislation to date is the Animal Welfare Act (AWA) 2006.

\section{THE ANIMAL WELFARE ACT 2006 - AN OVERVIEW}

The AWA is the only statute to date where the concept of animal sentience is even mentioned. The Act expressly repealed the PAA and received Royal Assent on the $8^{\text {th }}$ November $2006,{ }^{49}$ coming fully into force by the $8^{\text {th }}$ April 2007. The parameters of the legislation were ambitious, being '... the first review of pet law in 94 years ... the [AWA] combined more than 20 pieces of legislation into one'. ${ }^{50}$ This strengthened the position under the PAA as it introduced new offences and placed new duties onto the owner. One significant difference is that the AWA is designed to be proactive, allowing action to be taken before the animal has suffered, unlike the reactive approach of the PAA.

S.1(1) AWA defines its scope, '... in this Act, except subsections (4) and (5), "animal" means a vertebrate other than man'. ${ }^{51}$ Importantly for this paper, the explanatory notes refer to animals as 'sentient beings'; however, this does not legally recognise them as such, since these notes simply explain the reasoning behind the statute. Nevertheless, the notes equate being a vertebrate with being 'sentient' 52 and therefore, capable of feeling or experiencing pain and/or suffering and it is possible to extend the definition to include invertebrates under s.1(3)(a) should the need arise. There are important exceptions to the AWA's application however, s.58(1) states, '... nothing in this Act applies to anything lawfully done under the Animals (Scientific Procedures) Act 1986 (c.14) ${ }^{53}$ unless it transpires that the licensing procedures under that Act have not been complied with. Furthermore, s.59 expressly excludes fishing from the AWA. ${ }^{54}$

\footnotetext{
49 Animal Welfare Act 2006, Explanatory Notes.

50 'Animal Welfare Act Ethics Guide' (BBC Online, n.d.) < http://www.bbc.co.uk/ethics/ animals/overview/latest.shtml> accessed 1 August 2016.

51 Animal Welfare Act 2006, s 1(1).

52 Ibid., Explanatory Notes, s 1, Note 11.

53 Ibid., s 58(1).

54 Ibid., s 59.
} 


\section{THE AWA AND HORSES}

The Act places the onus of care onto the owner or keeper of a horse to ensure that the animal's basic welfare needs are met. ${ }^{55}$ While this demonstrates the government's recognition that there is a need for further law on this point, it is important to note that the AWA does not impose a duty of care on an owner but instead simply a duty. This is key because a duty is simply a responsibility; a duty of care is a legal obligation, a point to which this paper will return. s.9 AWA was incorporated to encourage the promotion of animal welfare, s.9(2) sets out an owner(s) or keeper(s) duties in relation to that animal. It is a criminal offence under s.9(1) ${ }^{56}$ if the welfare needs of an animal for which a person is responsible are not met. The provisions outlined under s.9(2) are the minimum standard an owner or keeper should aspire to. This includes the need for: (1) a suitable environment, and (2) diet, (3) to be able to exhibit normal behaviour patterns, (4) to be housed with, or apart from, other animals (as appropriate), and (5) to be protected from pain, suffering, injury and disease. ${ }^{57}$ In equine specific terms, this would normally mean one horse per stable of at least minimum measurements. It would require at least around one acre of grazing per animal in a herd environment but separated from overly aggressive horses as necessary and adequate veterinary and farrier care. These five needs, given a statutory footing by the AWA have their origins in the Report of the Technical Committee to Enquire into the Welfare of Animals Kept under Intensive Livestock Husbandry Systems 1965, otherwise known as the Brambell Report. ${ }^{58}$ This work identified that '... an animal should at least have sufficient freedom of movement to be able without difficulty, to turn around, groom itself, get up, lie down and stretch its limbs'. ${ }^{59}$ Subsequently, what became the Farm Animal Welfare Council (FAWC) incorporated the concepts of the Brambell Report, resulting in the 'five freedoms' ${ }^{60}$ Although originally concepts

\footnotetext{
55 'Animal Welfare Guidance' (DEFRA, 2013) <https://www.gov.uk/guidance/animalwelfare > accessed 1 August 2016.

56 Animal Welfare Act 2006, s 9(1).

${ }^{57}$ Ibid., s 9(2)(a)-(e).

${ }^{58}$ Roger Brambell, Report of the Technical Committee to Enquire into the Welfare of Animals Kept under Intensive Livestock Husbandry Systems (Her Majesty's Stationary Office 1965).

${ }^{59}$ Ibid., 84.

60 'Five Freedoms' (Farm Animal Welfare Council, 1979) <http://webarchive. nationalarchives.gov.uk/20121007104210/http:/www.fawc.org.uk/freedoms.htm> accessed 15 August 2016.
} 
used in relation to intensive farming, these freedoms are now applied to all animals.

\section{ISSUES OF CONCERN REGARDING THE ANIMAL WELFARE ACT 2006}

Even though animal sentience is cited in the margins of the AWA, the overall position of the concept is more complicated to analyse. The position in this paper is that there have been significant failures with animal welfare legislation which concern all three branches of government, not just the way that the AWA was drafted when it passed through Parliament.

In November 2016, it was revealed by a coalition of veterinary organisations that two-thirds of pet owners are unaware of their pets' legal welfare needs. ${ }^{61}$ This is a cause for concern given the number of all animals currently kept as pets, which in 2016 was estimated to be 57 million. ${ }^{62}$ Turning to equines, the World Horse Welfare and Eurogroup for Animals released a report in 2015 into the estimated numbers of equines within Europe. The number thought to be in the United Kingdom was just under $800,000 .{ }^{63}$ That said it is notoriously difficult to accurately determine the number of equines in Europe as these kinds of surveys have standard deviations of up to $60 \% .^{64}$ This in itself is a welfare concern as a major plank of any coherent welfare regime is an accurate census. Animals not accounted for are obviously at risk of falling outside the reach of the law.

Under the AWA, a person will be found to be in breach of their duty 'if he does not take such steps as are reasonable in all the circumstances to ensure that the needs of an animal for which he is responsible are met to the extent required by good practice'. ${ }^{65}$ The case of $R$ (on the application of the Royal Society for the Prevention of Cruelty to Animals) v $C$ from 2006 provides guidance in respect to 'reasonableness'. The RSPCA brought forward a prosecution under the old PAA.

61 'UK Pets at Risk as Two-Thirds of Owners Unaware of Welfare Needs' (British Veterinary Association (BVA), 2016) <https://www.bva.co.uk/news-campaigns-andpolicy/newsroom/news-releases/uk-pets-at-risk-as-two-thirds-of-owners-unaware-oflegal-welfare-needs $>$ accessed 4 November 2016.

62 'Pet Population 2016' (Pet Food Manufactures Association, n.d.) <http://www.pfma. org.uk/pet-population-2016> accessed 4 November 2016.

63 'Removing the Blinkers' (World Horse Welfare, n.d.) <http://www.worldhorsewelfare. org/Removing-the-Blinkers> accessed 13 July 2017.

64 Rhys Evans and Celine Vial (eds), The New Equine Economy in the $21^{\text {st }}$ Century (Wageningen Academic Press 2016) 19.

65 Animal Welfare Act 2006, s 9(1). 
The RSPCA argued on appeal, 'the test of reasonableness should be confined, so that it is applied objectively, and that any subjective element should be resisted as being outside the relevant test'. ${ }^{66}$ The judges nevertheless rejected this argument upholding the court's original ruling that the defendant's age and position within the home should be considered in respect to accountability. This does accord with a general move away from a 'one-size-fits-all' approach to a more subjective view found in other areas of criminal law. ${ }^{67}$ The jurisprudence in this particular area is not however a model of clarity: in terms of s.9(1) AWA, 'all the circumstances' of the case may then include taking account of factors such as age, level of responsibility that can be expected, animal welfare knowledge and so on, and these factors can be and should be taken into account by the court when presiding over a case. However, in the 2013 case of $R$ (on the application of Gray and Another) v Aylesbury Crown Court it was held on appeal that under the AWA 2006 's.9(1) set a purely objective standard of care which a person responsible for an animal was required to provide'. ${ }^{68}$ Both judgements formally conclude that s.9(1) is an objective standard that is to be met but leave a question mark over how subjectively that can be applied. This is important for this paper because a court determining the level of care required for a horse, if it is to have subjective elements, would have to take into account the vast disagreements there are about what is and is not acceptable in the keeping and training of horses. Traditional cowboy methods including those used for breaking, castrating and branding ${ }^{69}$ would be viewed with horror in the English riding sector. Even within that latter discipline there has been much debate about the use of such as the Rollkur method of training which involves excessive forced bending of the neck to achieve a classical shape. ${ }^{70}$ Further, bare foot trimming has its advocates but is treated as cruelty by the RSPCA if carried out to a certain degree. ${ }^{71}$

66 [2006], 1069, (Admin) EWHC (QB).

67 See, for instance, $R \vee G$ and Another [2003] UKHL 50, [2004] AC 1034, where Caldwell objective recklessness was rejected as the standard in criminal damage cases, the defendants in this case were children.

68 [2013], 500 (Admin) EWHC (QB).

69 William Steinkraus, The Horse in Sport (Macdonald Orbis Ltd 1987) 178-201. See also current proposals to eject the western riding discipline of Reining from FEI governance over welfare concerns across the entire sport; Pippa Cuckson 'FEI Set to Eject the Discipline of Reining at the End of 2019' (Horse Canada Website, 2019) <https:// horse-canada.com/horse-news/fei-set-eject-reining-end-2019> accessed 15 July 2019.

70 "'Blue Tongue" Rollkur Dressage Video Row Escalates' (Horse and Hound Online, 2009) <http://www.horseandhound.co.uk/dressage/blue-tongue-rollkur-dressage-videorow-escalates-291211> accessed 15 July 2019.

71 See, for instance, the conviction of Ben Street on 2nd October 2014, in Stafford 
However, if the standard were objective then reference would need to be had to what might be described as 'industry standards'. This is relatively straightforward with dogs and cats as there is a raft of laws and regulations to be met when running a kennels or cattery. The Animal Boarding Establishments Act 1963 regulates animal accommodation. The act provides that an establishment must have the required license attained from the local authority ${ }^{72}$ and can be subject to inspection. ${ }^{73}$ In stark contrast, there is no legislation currently in place to regulate the creation and operation of a livery yard. This is as distinct from a riding establishment where instruction on riding, often on a commercial basis, is given, these are regulated by such as the Animal Welfare (Licensing of Activities Involving Animals) (England) Regulations 2018. The lack of regulation of liveries has been a problem area for equine welfare commentators for some time, '[t]here is currently no requirement for livery yards to be licensed in any way, and the standard of care at DIY yards has been a growing cause for concern' ${ }^{74}$ Some years on from this statement, the following is typical of the local authority approach. "[L]ivery yards ... do not require licensing [but] ... are currently being considered for local authority licensing and should this become a requirement in the future, [council policy] will be amended accordingly'. ${ }^{75}$ Having an unregulated system allows scope for abuse as in practical terms, without licensing there is no system of recording the number of livery yards, the addresses, the proprietors or their backgrounds. Among other things, this presents the potential of a biohazard concern. Highly contagious outbreaks such as "strangles' ${ }^{76}$ and the equine influenza outbreak that briefly, and yet expensively, paralysed UK horse racing in $2019,{ }^{77}$ are harder to contain if there is no system of inspection in place that liaises

Magistrates Court. Charges were brought under s 4(1) and 9(1) AWA 2006 by the RSPCA with the support of the Farriers' Registration Council. The charges related to the trimming of horses' hooves during Mr Street's normal occupation as a 'Barefoot Trimmer', an alternative to a Registered Farrier for trimming hooves although not for affixing shoes, etc. 72 Animal Boarding Establishments Act 1963, s 1.

73 Ibid., s 2.

74 'DEFRA Pressed to Support Yard Licensing' (Horse \& Hound Online, 2006) <http:// www.horseandhound.co.uk/news/defra-pressed-to-support-yard-licensing-82430> accessed 2 July 2017.

75 'North Hertfordshire District Council Animal Licensing Policy' (NHDC, 2013) <https://www.north-herts.gov.uk/sites/northherts-cms/files/animal_licensing_policy.pdf> accessed 2 July 2017.

76 Streptococcus equi ssp equi.

77 Frank Keogh, 'Equine Flu: British Horse Racing Meetings Cancelled Because of Equine Flu Outbreak' (BBC Sport Online, 2019) < https://www.bbc.co.uk/sport/horseracing/47152882> accessed on 19 March 2019. 
with local veterinary practices and identifies high-risk areas. The AWA would apply to the individual owners of the horses who reside on the property and the proprietor regardless of the enforcement of a license. However, failing to have a system to license an establishment through an administrative body means that it cannot be clear whether the correct standards of the Act are being complied with.

In summary, if there are comparatively few controls other than town planning, applicable to opening and running a livery, no mandatory local authority inspections or licensing procedures and no oversight other than through entirely voluntary accreditation with the British Horse Society, then there are therefore no appreciable 'industry standards' to adhere to. Thus, it is difficult to see how even an objective test for standard of care, such as that under the AWA, never mind one that has nebulous subjective elements, is effective with respect to equines.

\section{WHAT IS A 'DUTY' IN THIS CONTEXT?}

Whether animal sentience is or is not centrally placed in UK animal welfare legislation is only part of the story, however. As mentioned earlier in this paper, having sidestepped statutory enshrinement of the concept of animal sentience as its centrepiece, the AWA relies on the concept of a 'duty' placed on the human concerned in relation to the order of life that is his or her responsibility. This is an interesting and telling choice of words. Two to three percent of the population is vegetarian or vegan all the time ${ }^{78}$ and an undetermined number are 'meat reductionists' or self-styled 'pescatarians' who will only eat seafood in addition to vegetarian products. This produces an obvious paradox for Parliament as animal welfare legislation must take account of the fact that the ultimate violence of death must be legal in a largely omnivorous society. The manner of that death is a sensitive subject, so bound up is it with cultural mores and religious belief. In point of fact the EU definition of animal sentience would not itself satisfy all sides in that debate as it implicitly makes allowance for ritual slaughter methods, mandating:

...full regard to the welfare requirements of animals, while respecting the legislative or administrative provisions and customs of the EU countries relating in particular to religious rites, cultural traditions and regional heritage. ${ }^{79}$

78 'Facts and Figures' (Vegetarian Society UK, n.d.) <https://www.vegsoc.org/info-hub/ facts-and-figures $>$ accessed 20 March 2019.

79 Article 13 of Title II, Lisbon Treaty which came into force in 2009. 
There is after all much greater variance in views in the debate on the nature of animal rights ${ }^{80}$ than there is about the nature of human rights.

This may well be why the Act was drafted with the vague notion of 'duty', imprecise even with its guideline principles in s.9(2) in place. In contrast, in Queensland, Australia however, the Animal Care and Protection Act 2001 clearly identifies who the legislation pertains to and uses specific wording. It explicitly states that a person in charge of an animal owes a duty to it and that they must not breach that duty, ${ }^{81}$ implying a full 'duty of care' much more familiar to common lawyers. Elsewhere in English law the position is binary, either a duty of care exists, or it does not. There is famously a test for it in tort in Donoghue $v$ Stevenson, ${ }^{82}$ developed in Caparro v Dickman ${ }^{83}$ and if it is not found no liability ensues, no matter how poorly the defendant has treated the claimant. There are a severely limited number of situations in criminal law where a duty of care will be held to have been in existence when an accused has failed to act, in neglect cases predominantly. Examples include where there is a parent or guardian relationship such as in Gibbons $v$ Proctor $^{84}$ and where a certain degree of responsibility has been assumed by taking steps, however ineffectual, to care for someone as in $R v$ Stone and Dobinson. ${ }^{85}$ There is no 'Good Samaritan' law in the United Kingdom so if no duty exists, in law, if not in moral terms, a person can stand by and not intervene, even to prevent death, without sanction. The position in the AWA is much more indeterminate and therefore ineffectual. This is likely to reduce its deterrent effect as well.

There are ways in which the rules of statutory interpretation give the courts the ability to develop an unclear or inadequate statutory position. In Sweet $v$ Parsley ${ }^{86}$ mens rea was inserted into a statute where none had been drafted, $R v$ Allen $^{87}$ is a good example of the 'Golden Rule' remedying a defective statutory provision, and in $R v$ Bentham $^{88}$ the court interpreted firearms legislation purposively to overcome an anomaly in an act. Furthermore, the courts have long

80 Jonathan Merritt, Regulating Sport for the Non-Human Athlete: Horses for Courses (Lexington Books 2019) 96; and see Tom Regan, 'The Case for Animal Rights' in Susan Armstrong and Richard Botzler (eds), The Animal Ethics Reader (Routledge 2003).

81 Animal Care and Protection Act 2001, s 17(1-2).

82 [1932] UKHL 100.

83 [1990] UKHL 2.

84 (1918) 13 Cr App Rep 134.

85 [1977] 1 QB 354.

86 [1970] AC 132.

87 (1872) LR 1 CCR 367.

88 [2005] UKHL 18. 
been using 'intrinsic aids' to interpretation, which would include the explanatory note where the word 'sentience' is found in the Act, to assist with interpreting the ethos behind the rest of the legislation. These methods could very well have been used to give effect to the concept of the animal as sentient in case outcomes since the TFEU came into force but have not as yet been employed.

The problem discussed above is compounded by further ambiguities in the Act. As an example, in s.4, regarding the prevention of harm, the term 'unnecessary suffering' is found. This must be a subjective term, as any objective measure of 'unnecessary suffering' is not easy to arrive at. There is some clarity on the scope of this term from the RSPCA Annual Prosecution Report 2009, which records that an owner received a written caution under S.4 for failure to follow veterinary advice in respect to their obese canines. The report states that '[o]wners now have a legal responsibility to feed and exercise their pets properly'. ${ }^{89}$ This also makes clear that the scope of 'unnecessary suffering' is beyond simply intentional physical abuse, but also includes harm caused indirectly, or accidently through lack of knowledge. This document hardly has the status of a legal precedent though. In respect of horses however, there can be marked disagreement over what constitutes an underfed or overfed horse other than in very extreme cases. This is because of the nature of their diet, seasonal grazing patterns and a lack of consistency regarding acceptable condition across the $80^{90}$ or so horse sport disciplines in the world. To one person a horse may be in 'show condition' but to another, it is verging on the obese and risking laminitis. ${ }^{91}$ This subjectivity does not help the cause of promoting consistent standards of equine welfare.

\section{ENFORCEABILITY OF THE ACT}

The AWA's enforceability provides another difficult issue when determining whether animal sentience is adequately considered in law. Currently there is no specific body or organisation that is under a statutory duty to enforce the AWA. S.51 imposes a discretionary duty upon national and local authorities to appoint 'inspectors'. 'The RSPCA exercises its right to act as private prosecutor under s.6 (1) of the Prosecution of Offences Act 1985. It is responsible for over 90\% of

\footnotetext{
89 Prosecutions Department Annual Report (RSPCA, 2009).

90 A number which may seem surprising but see for instance William Steinkraus, The Horse in Sport (Macdonald Orbis Ltd 1987).

91 See also $n$ 34, a foot condition often brought on by the horse being overweight through grazing on too much lush sugary pasture.
} 
prosecution activity on animal welfare issues ${ }^{92}$ That leaves $10 \%$ of prosecutions being brought by local authorities, the Crown Prosecution Service (CPS), and other private individuals. Prosecutions brought in respect to animal cruelty under s.4 (unnecessary suffering), s.8 (fighting etc.) and s.9 (duty of the person responsible) are triable only summarily. ${ }^{93}$ There is also the option under s.33(1) to deprive the owner of their animal, ${ }^{94}$ and finally under s.34(1) an owner can be disqualified from ownership for a specified period of time. ${ }^{95}$ Given the potential severity of outcome, a criminal conviction albeit in the magistrates court, and the consequences for the animal, the rather hotchpotch arrangements for who is to prosecute, is unsatisfactory. This position is indeed criticised by the Wooler Report 2014 , in which it is stated that:

the only strategy, such as it is, seems to be an ongoing assumption by the State that it can opt out of responsibility for the implementation and enforcement of animal protection legislation...because both the obligation and the cost will be picked up by the RSPCA. ${ }^{96}$

This presents a further issue as not-for-profit organisations such as the RSPCA do not have the resources to consistently investigate, enforce, regulate and prosecute under the Act. The report itself was after all in response to heavy criticism of the RSPCA for their private prosecution costs. This is another particular concern for those concerned with the health and welfare of horses because the RSPCA is barely coping with the number of complaints it has to process regarding companion animals and the space and expertise required to deal with equine cases is difficult and expensive to procure. ${ }^{97}$

It is the organs of the state that owe a responsibility to effectively enforce legislation which has been enacted. Given the above points it is fair to say that the state has so far failed to uphold animal welfare principles and law as effectively as

\footnotetext{
92 'Enforcement of the Animal Welfare Act' (Parliamentary Website, 2016) <https:// www.publications.parliament.uk/pa/cm201617/cmselect/cmenvfru/117/11709.htm> accessed 11 March 2017.

93 Animal Welfare Act 2006, s 32(1).

94 Ibid., s 33.

95 Ibid., s 34(1).

96 Stephen Wooler, The Independent Review of the Prosecution Activity of the Royal Society for the Prevention of Cruelty to Animals' (RSPCA 2014) $42<$ https://www.rspca. org.uk/webContent/staticImages/Downloads/WoolerReviewFinalSept2014.pdf > accessed 26 May 2019.

97 Merritt (n 82) 32 and n 58 therein.
} 
it could. This is true because firstly, as this paper has pointed out, the legislative process has failed to accommodate the changing social construction of animals, including in particular horses, as sentient in the drafting of that law. Secondly, it is a contradiction to have legislation enacted by Parliament when there is a real lack of consistency and clarity regarding enforcement. Thirdly there are difficulties in bringing cases because of the ambiguities in the drafting of the act. It is not the first time these issues have been raised. The Royal College of Veterinary Surgeons (RCVS) carried out a 'Post-Legislative Scrutiny 2010 Consultation Process', within that work, significant issues were indicated surrounding the enforcement of the AWA. For example:

... local authority enforcement teams tend to be small and resources are increasingly stretched, meaning that carrying out in-depth investigations into breaches of the Act can be difficult. Furthermore, constraints on police time can result in investigations into animal welfare offences taking second place to investigations into other offences. ${ }^{98}$

Nearly a decade on from this, the same issues still arise because the effects of the global financial crisis and successive UK administrations that have prioritised fiscal restraint in public finances have not helped. In fact, written evidence by Mike Radford, Dr Fiona Cooke and Professor Sheila Crispin to the Environment, Food and Rural Affairs Parliamentary Sub-Committee, published in 2016 highlighted that, 'a significant proportion (just under $40 \%$ in England (just under $35 \%$ in Great Britain)) of local authorities had failed to appoint any inspectors under the authority of s.51. ${ }^{99}$ In respect of those authorities which had made appointments, their effectiveness was also questioned in this evidence as only $17 \%$ in England (11\% across the whole United Kingdom) of these authorities had inspectors dealing with welfare cases on a daily basis. These figures are a clear indication that lack of a statutory duty to enforce automatically places the AWA as a low priority issue for local authorities, who will be on tight budgets. In the Chancellor of the Exchequer's Spring 2019 Statement there was some signalling of

98 Response of the Royal College of Veterinary Surgeons, (RCVS), letter dated $6^{\text {th }}$ September 2010, Animal Welfare Act 2006 Post-Legislative Scrutiny, 2010 Consultation Process.

99 'Evidence of Dr Fiona Cooke, BSc (Hons) MA Law; Professor Shelia Crispin, MA VetMB BSc PhD DVA DVOphthal DipECVO FRCVS; Mike Radford, OBE LLB' (Parliament Website, 2016) <http://data.parliament.uk/writtenevidence/committeeevidence. svc/evidencedocument/environment-food-and-rural-affairs-subcommittee/animal-welfaredomestic-pets/written/30660.pdf> accessed 11 March 2017. 
a loosening of the public purse strings enabled by lower borrowing forecasts and higher than expected tax receipts in January. ${ }^{100}$ Any feeling that the worst of 'austerity' is over however must be tempered by the likely short-term effect of Brexit on the economy, something the Chancellor himself acknowledged. Thus, the likelihood is that the tightening of resources centrally will continue for some time to come. This has the potential to be a circular issue as low prosecution levels could lead to higher offending and reoffending.

We should turn next to whether the sentencing guidelines adequately reflect the emergent societal conception of the animal as sentient.

\section{SENTIENCE AND SENTENCING...}

The maximum punishment that can be imposed for a s.4 or s. 8 offence under the AWA is a $£ 20,000$ fine and/or six months imprisonment ${ }^{101}$ and for a s. 9 offence it is a Level 5 fine and/or six months imprisonment. ${ }^{102}$ The starting point for 'attempt to kill/torture; animal baiting/conducting or permitting cock-fighting etc.; prolonged neglect' - is 18 weeks imprisonment with a maximum of 26 weeks ${ }^{103}$ with the usual discount for a guilty plea. An offender may also be subject to a deprivation of ownership, or disqualification of ownership order ${ }^{104}$ at the discretion of the magistrates or judge.

It is not intended to enter into a discussion about whether the severity of sentences is in fact a deterrent; the relationship between harsh punishment, deterrence and recidivism generally is a hotly disputed one among penologists. ${ }^{105}$ That said, on the assumption that severity of punishment should match the severity of the crime, these are not particularly harsh punishments. It does not appear that these sanctions take into account the evolving recognition of the animal's sentience, and rather reflects their traditional status as property instead. In fact, England and Wales have some of the most lenient sentencing guidelines globally in this area. As an example, in Louisiana the maximum sentence for animal cruelty offences is

\footnotetext{
100 'Spring Statement 2019: What You Need to Know' (gov.uk, 13 March 2019) <https:// www.gov.uk/government/news/spring-statement-2019-what-you-need-to-know> accessed 20 March 2019.

101 'Animal Cruelty' (Sentencing Council, 24 April 2017)<https://www.sentencingcouncil. org.uk/offences/magistrates-court/item/animal-cruelty-revised-2017> accessed 31 March 2019.

102 Ibid.

103 Ibid.

104 Ibid.

105 Newburn (n 11) 677-701.
} 
10 years imprisonment, ${ }^{106}$ in Latvia and Northern Ireland it is five years, in Italy it is three years' incarceration. ${ }^{107}$ It is difficult to understand why the UK jurisdiction is at the more lenient end of the spectrum given that as a nation, we are quick to profess being animal lovers.

The AWA explanatory notes contain the term 'sentient', and although not legally binding it is a concept that the legislators have clearly recognised and this acknowledgement could have been reflected in the sentencing guidelines notwithstanding the word's absence from any actual legislative provision. Furthermore, irrespective of the repeal that is taking place and the discussion in this paper on that, EU law had and has primacy to date. ${ }^{108}$ Although the Act predates the Lisbon Treaty, the sentencing guidelines are another matter as they can be regularly updated. As such, they represent a missed opportunity to incorporate the tenets of Article 13 TFEU from the point of it coming into force onwards. These sentencing guidelines represent a failure in terms of historic compliance with EU law as well in that case. Additionally, given the current impossibility of predicting the post-Brexit legal landscape, that failure may be a continuing one if EU law still has some role to play after the United Kingdom leaves the bloc.

In 1911, at the time of the PAA, the concept of sentience was not yet recognised, there was no duty of care imposed upon the owners of animals, and the five needs of an animal were not paramount either. Despite this, the sentencing under the PAA is equivalent to, if not more severe than it is under the AWA. This is so because of the possibility of 'hard labour'. ${ }^{109}$ This type of punishment is no longer a possibility in the UK penal system, ${ }^{110}$ but the salient point is that over 100 years ago, the legislators considered it an appropriate sanction given the severity of the crime. This will have been intended to influence public attitude to animal welfare and raise its importance. It is not suggested here that hard labour should be reintroduced to the UK penal system but with the absence of this aspect of the sanction, and its intended deterrence effect, there should be something to replace it. Either the term of incarceration or the possible fines should increase dramatically

\footnotetext{
106 Chapter 1 S.102.1 B. (1)(4) Louisiana Cruelty to Animals Statutes.

107 'Sentencing for Animal Cruelty: The Arguments for an Increase' (RSPCA, 2017) <http://politicalanimal.org.uk/wp-content/uploads/2017/06/Sentencingbriefing-1.pdf> accessed on 26 March 2019.

108 European Communities Act 1972, s 2(4); R (Factortame Ltd) v Secretary of State for Transport (No 2) [1991] 1 AC 603.

109 Protection of Animals Act 1911, s 1.

${ }^{110}$ However, many jurisdictions, including some in the United States, do still use a form of 'chain gang' in their penal systems.
} 
to send an equivalent or clearer signal. Without this, the level of sentencing for cruelty to animals has not significantly changed between 1911 and 2006 and in some respects, may be viewed as less appropriate. Given the lack of agreement about the deterrence effect of so-called 'tough sentencing', an alternative would be a presumption in favour of very lengthy bans on the keeping of any animal, not just equines and a presumption for the maximum amount of community service. ${ }^{111}$ This to be served irrespective of the inconvenience or financial hardship it might impose. This lack of progression flies in the face of our increased understanding of animals as sentient creatures. This new recognition should mean the enforcement of the 'five needs' warrants a more severe sanction than that which existed under the PAA, albeit within modern sentencing constraints and the Human Rights Act 1998.

The draft Bill does include a provision to increase the sentences available to the courts under the AWA:

(2) In subsection (1) (penalty for offence under section 4, 5, 6(1), 6(2), 7 or 8 of the Animal Welfare Act 2006), for the words from 'on summary conviction' to the end substitute "-

(a) on summary conviction, to imprisonment for a term not exceeding 51 weeks, or to a fine, or to both; (b) on conviction on indictment, to imprisonment for a term not exceeding 5 years, or to a fine, or to both.

This is a welcome development of course, but it remains to be seen whether this provision survives Parliamentary debate. There is also no guarantee that this Bill will get Parliamentary time at all, as one of the outcomes of the current impasse in the House of Commons over Brexit generally is a General Election. Even if enacted as drafted, the research this article is based on makes it clear that the problem may be as much in the application of the law as it is in how it is legislated.

The AWA Disqualification of Ownership Order (DOO) presents a problem as well. There is a question as to who ensures that it is not breached. Anti-Social Behaviour Orders (ASBOs) and their modern incarnation, the Injunction to Prevent Nuisance and Annoyance (IPNA) ${ }^{112}$ incur prison sentences if they are not complied with. There is, however, a far greater chance that such breaches will be reported by human victims. The victim in the case of the DOO would be the animal acquired in defiance of the prohibition, who would be quite voiceless. In addition, with an

111 This has undergone many changes in nomenclature, 'community payback', 'community punishment order' being just two.

112 Anti-Social Behaviour, Crime and Policing Act 2014, s 1. 
IPNA, the police will easily have access to a record that an order is in place and can act accordingly. A person walking down the street with a dog on a lead or even more so, having an equine on pasture they have rented will not in and of itself so readily attract a report from a concerned citizen. This is unless there is personal knowledge, held by the person reporting, about any such disqualification. Animals require humans to enforce the order on their behalf; they are self-evidently quite unable to do so themselves. The irony is that humans engaged in a noisy party or having an excess of trash in a garden are more likely to face enforcement action than the breach of an AWA DOO. Despite the fact that such a breach puts a sentient being at risk of actual harm rather than just alarm, harassment or distress. As an example of this very problem, in Beverley Magistrates Court on 5 August 2016, a defendant 'was already serving an 18-month ban on owning and keeping horses and dogs for similar offences and causing unnecessary suffering to two horses, [but] ignored the court order and continued to neglect animals with complete disregard for the law'. ${ }^{113}$ The defendant was sentenced to 20 weeks in prison, with an ownership ban of horses for a period of 10 years, and a DOO for the horses previously in her care. ${ }^{114}$ Justice was perhaps done in this case, but it also serves to highlight that there is likely to be a significant 'dark figure' in criminal statistics regarding those who flout AWA orders and are not discovered. There is a clear and present need for a mechanism to regulate those who have been convicted of animal-related offences.

One argument that has been put forward is for an animal abuser registry, similar to that for registered sex offenders. This would allow for identification of abusers and prevent them from obtaining animals in defiance of a ban. It would also put animal abuse on a par with abuse against other sentient beings, i.e. humans. For Sweeney, 'at present the perverse position is we rely on the criminal convicted of cruelty to animals to refrain from further abuse of animals. That is akin to trusting a drunk driver to voluntarily refrain from alcohol'. ${ }^{115}$ Sweeney himself calls for a register to monitor proven offenders. This is of obvious benefit to animal welfare but also because there is every possibility that these offenders'

113 Sarah Radford, 'Dealer Who Flouted Horse Keeping Ban Jailed for Neglect' (Horse and Hound Online, 2016) <http://www.horseandhound.co.uk/news/dealer-flouted-horsekeeping-ban-jailed-neglect-588059> accessed on 12 September 2016.

114 Dan Bean, 'Horse Dealer Jailed for Neglect' (York Press Online, 2016) <http://www. yorkpress.co.uk/news/14673521.Horse_dealer_jailed_for_neglect_two_more_ sentenced $>$ accessed 26 March 2019.

115 Noel Sweeney, 'Why We Need an Animal Abuser Registry?' (Shensmith Barristers, n.d.) $<$ https://www.shensmithbarristers.co.uk/direct-access-barristers/noel-sweeney> accessed 26 March 2019. 
mindset could lead to cruelty to humans. ${ }^{116}$ This is an area which is clearly of public concern as in 2016, over 500,000 people signed a petition for the introduction of an animal abusers register after a particular case of cruelty came to light ${ }^{117}$. Such a registry was a recommendation put to the government during a review of the AWA, specifically it was stated that, "it is very difficult to track those who have been banned from keeping animals. An accessible register could play an important role in protecting animals and prevent abusers from accessing animals.' ${ }^{18}$ The current position of simply expecting offenders to refrain from reoffending or relying on chance reports from concerned and informed citizens is surely untenable.

\section{ANIMALS AND THEIR STATUS AS PROPERTY}

This study has already mooted the problem that hitherto the underlying legal principles in animal welfare legislation owe more to their historical perception as tangible property than they do to any concept of consciousness and sentience. As property, horses and other animals in England and Wales do not possess legal personality, this in turn prevents animals from being capable of holding legal rights per se. This may be unsurprising in a capitalist society as particularly in terms of horses that property value can be considerable. Champion racehorses fetch eye-watering sums and can even have their own media career ${ }^{119}$ which in turn provides further income for the owner on top of potential stud fees and the like. Even in less popular equestrianism, the figures can be jaw-dropping and top-level competition horses can be so valuable they are often owned by a syndicate. ${ }^{120}$ None of this helps the welfare position though the high levels of care these horses get are a reflection of their monetary value, not their position as sentient

116 See Clifton Flynn, 'Examining the Links between Animal Abuse and Human Violence' (2013) 55(5) Crime Law and Social Change, 453-468.

117 Elsa Vulliamy, 'Half a Million Sign Petition to Introduce Animal Cruelty Register after "Worst Ever" Attack on Dog Chunky the Chihuahua' (Independent Online, 2016) <http://www.independent.co.uk/news/uk/home-news/half-a-million-sign-petition-tointroduce-animal-cruelty-register-after-attack-on-chihuahua-a6886186.html $>$ accessed 11 March 2017.

118 'Animal Welfare in England: Domestic Pets' (The Environmental, Food and Rural Affairs Committee, 2016) <https://www.publications.parliament.uk/pa/cm201617/ cmselect/cmenvfru/117/11709.htm> accessed 11 March 2017.

119 For instance, Australian champion racehorse Black Caviar featured on the front cover of Vogue Australia, December 2012 Issue.

${ }^{120}$ For example, London 2012 Team GB's gold medal winning dressage mount Valegro was to be sold for at least a reported $£ 3 \mathrm{~m}$ but for a change of heart by the syndicate. See 


\section{THE DENNING LAW JOURNAL}

beings. There is a significant problem in the United Kingdom with racehorses that fall into neglect or are slaughtered ${ }^{121}$ once their winning potential, and thus their value, is gone.

There are a number of pieces of legislation applied to animals as property, such as the Consumer Rights Act 2015, Theft Act 1968 and Theft Act 1978. An animal may also be classed as property capable of being 'damaged or destroyed' under the terms of the Criminal Damage Act 1971. In this respect, CPS guidance states, 'A charge of criminal damage may be appropriate in the event of the death or injury of an animal owned by someone other than the defendant'. ${ }^{122}$ Indeed, Brooman and Legge go so far as to say, '...[t]he treatment of animals as property without rights is a common feature of the law relating to animals: an abuse of an animal is an abuse of the human interest in the animal concerned'. ${ }^{23}$ Current legislation places animals within the same category as an inanimate object; this flies in the face of the recognition of animals as sentient beings. The seeds of this anthropocentric approach are found in the very earliest development of English and Welsh law:

in the beginning of the world, we are informed by holy writ, the all-bountiful creator gave to man 'dominion over all of the earth; and over the fish of the sea, and over the fowl of the air, and over every living thing that moveth upon the earth'. This is the only true and solid foundation of man's dominion over external things, whatever airy metaphysical notions may have been started by fanciful writers upon this subject. The earth, therefore, and all things therein, are the general property of all mankind, exclusive of all other beings, from the immediate gift of the creator. ${ }^{124}$

It is worth quoting this passage in full as it also demonstrates a resistance to new ideas about the place of animals in the wider ecosystem, justified by a

'Carl Hester Hopes to Keep Dressage Horse Valegro in UK' (BBC Sport Online, 2012) <https://www.bbc.co.uk/sport/equestrian/20780618> accessed 21 March 2019.

121 The British Thoroughbred Retraining Centre (BTRC) is perhaps the best known of many racehorse re-homing charities that exist because of this very problem, <www. britishtrc.co.uk> accessed 31 March 2019.

122 'Charging Standard in Relation to Dangerous Dog Offences and Offences Involving Domestic and Captive Animals' (The Crown Prosecution Service (CPS), n.d.) <http:// www.cps.gov.uk/legal/d_to_g/offences_involving_domestic_and_captive_animals> accessed 26 March 2019.

123 Brooman and Legge (n 47) 50.

124 Ibid., 51. 
somewhat fundamentalist interpretation of Christian teachings still not unknown today. In a survey of pastors into why animal rights do not feature in church sermons very much, the responses, 'Animals do not have souls', 'Humans have dominion' and 'Mercy does not apply to animals', are perhaps most striking. ${ }^{125}$

As the vociferous debate over such as trophy hunting, fox hunting and bull fighting shows, many humans still feel a sense of entitlement over animals. Furthermore, historically the common law has regarded and given the greatest protection to:

... those animals designated as useful, and the least protection to those ferae naturae. Useful animals [e.g., horses, cattle and sheep] are regarded as having intrinsic value, and are given the same protection as is given to goods; but, at common law, animals of a base nature are not regarded as property to the extent of being subjects of larceny, nor could a criminal action be brought for maliciously killing an animal of a base nature [e.g., dogs and cats]. ${ }^{126}$

For Francione, 'animals are regarded merely as a means to human ends, which means that the law embodies the instrumentalist view of animals'. ${ }^{127}$

More recently, however, societal attitudes have developed and evolved in respect to many controversial issues, away from the biblical position, particularly in relation to capital punishment, child labour, LGBTQ rights and same-sex marriages. These changes reflect the increasingly secular nature of our society and an appetite for change. On a practical level, commentators are questioning the wisdom of an entirely anthropocentric approach to environmental regulation. This is why so much concern is expressed about the backward steps regarding climate change, environmentally damaging projects like oil pipelines and the protection afforded such as wild mustangs, taken by the current US administration. ${ }^{128}$ Such

125 'Evangelical Spirituality and Animal Ethics' (Sarx.org.uk. n.d.) <https://sarx.org.uk/ articles/christianity-and-animals/evangelical-spirituality/\#_ftn1> accessed on 21 March 2019.

126 Frank Childs, Principles of the Law of Personal Property, Chattels and Choses (Forgotten Books 1914) 35-36; see also David Favre, 'Living Property: A New Status for Animals within the Legal System' (2010) Marquette Law Review 1026.

127 Gary Francione, Rain without Thunder: The Ideology of the Animal Rights Movement (Temple University Press 1996) 25.

128 Oliver Milman, 'Trump's Alarming Environmental Rollback: What's Been Scrapped so far' (The Guardian Online, 2017) <https://www.theguardian.com/environment/2017/ jul/04/trump-emvironmental-rollback-epa-scrap-regulations $>$ accessed 1 September 2017. 
activity is criticised as unsustainable and eco-centrism or even biocentrism being advocated as an alternative driver for law making. ${ }^{129}$ Redgwell, however, does not quite go that far and seeks to simply water down anthropocentrism but for the same reasons, he advocates, '... a more diluted anthropocentrism which recognises the interrelatedness and interdependence of the natural world of which human beings form a part'. 130 Taylor goes further though, proposing to extend moral status from humans to nature as a whole, stating that each individual has inherent worth. For Taylor, 'from the perspective of a life-centred theory, we have prima facie moral obligations that are owed to wild plants and animals themselves as members of the Earth's biotic community. We are morally bound (other things being equal) to protect or promote their good for their sake'.131

Anthropocentrism and biocentrism occupy extreme ends of the spectrum. As a result, each creates different problems if fully adopted. Although society might not currently be in a position to adopt the ethics of biocentrism fully, our ability to start to recognise the need for a symbiotic relationship of mutualism to emerge, as opposed to our previous, almost parasitic, relationship demonstrates our willingness to develop. Our historical approach is one of a patchwork of law relying in theme at least, on religious texts as a foundation. This means that it is necessary to consider our past failings to avoid having a similarly patchwork future in respect of animal, and for this paper, equine welfare. Adopting a realist approach though, as around $97-98 \%$ of the UK population are meat eaters, ${ }^{132}$ adopting a strict biocentric stance could result in hostile opposition. For now, the acceptance of a diluted version of anthropocentrism may be the best way forward. One solution, which is realistic in this way, but takes account of the movement towards constructing animals as sentient more widely, would be to recognise a new category of property - 'living property'. Enhanced protection for animals is unlikely to occur until animals are no longer recognised simply as personal property. Laws can eventually change to match evolving social constructs, the decriminalisation of homosexual acts in the United Kingdom being one illustrative example. It is especially difficult at this time to tell whether the new draft Bill on welfare and animal sentience will ever get to be the change that is needed. At time

\footnotetext{
129 Newburn (n 11).

130 Catherine Redgwell, 'Life, the Universe and Everything: A Critique of Anthropocentric Rights' in Allan Boyle and Micheal Anderson (eds), Human Rights Approaches to Environmental Protection (Clarendon Press 1996) 71.

131 Paul Taylor, 'The Ethics of Respect for Nature' (1981) 3(3) Environmental Ethics 199. 132 See also (n 78) further, according to the NHS, only $2 \%$ of the UK population is vegetarian, see 'Vegetarian Health' (NHS, n.d.) <http://www.nhs.uk/Livewell/ Vegetarianhealth/Pages/Goingvegetarian.aspx> accessed on 1 September 2017.
} 
of writing, the Government is still in open conflict with the House of Commons over the direction of Brexit ${ }^{133}$ and a General Election is a very real possibility in the near future.

\section{THE JOURNEY TOWARDS A NEW LEGAL STATUS FOR ANIMALS - A COMPARATIVE VIEW}

Attitudes towards animals, their legal and social status and sentience are changing worldwide. This has had a tangible effect on animal welfare law in other countries. The explicit recognition of animals as sentient is evident in a number of jurisdictions. In 2015 the New Zealand Government, 'formally recognised animals as "sentient" beings by amending animal welfare legislation'. ${ }^{34}$ A year later, Canadian legislation in the Province of Quebec acknowledges that 'animals are not things. They are sentient beings and have biological needs'. ${ }^{135}$ Canada having previously enacted the Justice for Animals in Service Act (Quanto's Law) 2015. 'This enactment amends the [Canadian] Criminal Code to better protect law enforcement animals, military animals and service animals and to ensure that offenders who harm those animals ... are held fully accountable'.136 This Act provides a maximum prison sentence of five years with a mandatory minimum term of six months if the animal is killed. The wording of the act is wide, covering enforcement, military and service animals, many of which are police and military parade horses. This enactment came after a police dog which, during the course of his duties, was stabbed to death in 2013. The first charge under Quanto's Law was brought in August 2016 after the assault of a police dog. This demonstrates that although these animals' status is not considered akin to that of their handlers, it is acknowledging that their status should be regarded as higher than that of personal property. In the United Kingdom,

133 Shebab Khan, 'Brexit News - Live: General Election Looms as Theresa May Calls Cabinet Talks after MPs Leave Her EU Exit Plan in Chaos' (Independent Online, 25 March 2019) <https://www.independent.co.uk/news/uk/politics/brexit-news-live-theresamay-vote-result-deal-latest-updates-a8839781.html> accessed 25 March 2019.

134 Sophie McIntyre, 'Animals Are Now Legally Recognised as "Sentient" Beings in New Zealand' (Independent Online, 2015) <http://www.independent.co.uk/news/world/ australasia/animals-are-now-legally-recognised-as-sentient-beings-in-newzealand-10256006.html > accessed 4 October 2016.

135 'Quebec Bill Calls Animals 'Sentient Beings' and Includes Jail Time for Cruelty' (CBS News Online, 2015) <http://www.cbc.ca/news/canada/montreal/quebec-bill-callsanimals-sentient-beings-and-includes-jail-time-for-cruelty-1.3102399> accessed 4 October 2016.

136 Justice for Animals in Service Act (Quanto's Law) 2015. 
Members of Parliament debated the initiation of similar legislation in the House of Commons on the $14^{\text {th }}$ November 2016. This was prompted by an e-petition which was signed by $126,877^{137}$ people. The petition text read, 'I propose that UK Police Dogs and Horses be given protection that reflects their status if assaulted in the line of duty...' ${ }^{138}$ The Government response to the debate is interesting, part of it reads:

... it is unpalatable to think of police animals as 'equipment' as is inferred by the charges of criminal damage. This does not seem to convey the respect and gratitude police and public feel for the animals involved and their contribution to law enforcement and public safety. The Government has therefore agreed to explore whether there is more that the law should do to offer the most appropriate protections to police animals and all working animals. ${ }^{139}$

It is possible therefore that something resembling Quanto's Law might be enacted for England and Wales. The same route that Sarah's Law took, regarding a paedophile register, having been initiated by public concern similar to that which lead to Meghan's Law in the United States on the same issue. ${ }^{140}$ There are encouraging signs in the Written Ministerial Statement that prefaces the draft Animal Welfare (Sentencing and Recognition of Sentience) Bill 2017. Michael Gove commits that '[m]y proposed increased maximum penalties will also apply to convictions relating to attacks on service animals, including guide dogs, police and military dogs. ${ }^{141}$

137 'Police Dogs and Horses' Hansard, Volume 617 (Hansard, 2016) <https://hansard. parliament.uk/commons/2016-11-14/debates/D856FCAE-9EF4-49CF-99A0 AF5F379BEF94/PoliceDogsAndHorses> accessed 15 November 2016.

138 Ibid.

139 'Petition to Give Same Status to Police Dogs and Horses as Police Officers' (petition. parliament.uk, 10 April 2017) <https://petition.parliament.uk/petitions/168678?reveal_ response=yes $>$ accessed on 15 November 2016.

140 'Sarah's Law' Protects More Than 200 Children in First Year' (gov.uk, 4 April 2017) $<$ https://www.gov.uk/government/news/sarahs-law-protects-more-than-200-children-infirst-year> accessed 31 March 2019.

141 'Written Ministerial Statement, the Draft Animal Welfare (Sentencing and Recognition of Sentience) Bill 2017' (gov.uk, 2017) <https://assets.publishing.service.gov.uk/ government/uploads/system/uploads/attachment_data/file/666576/draft-animal-welfarebill-171212.pdf> accessed 25 March 2019. 


\section{CONCLUSION}

With a definite focus on the equine population of this country, this paper was written as a direct response to the Environment Secretary Michael Gove's plea for us to 'trust' the UK Parliament to legislate effectively to protect animal welfare, specifically with better recognition of the emerging concept of animal sentience. In November 2017, the definition of animal sentience in Article 13 TFEU was deliberately left out of the legislation designed to repeal the ECA 1973 and the Brexit process has rumbled on during the intervening 18 months or so before this paper was written. Trust in British politicians seems to be currently below even its usual low level as even the Prime Minister has castigated Parliament for 'indulging' itself over Brexit for far too long, criticising ordinary MPs generally rather than the usual target, the opposition. ${ }^{142}$ Nevertheless, the most methodologically sound approach to address Gove's words is to look at how the United Kingdom has protected animal welfare historically, irrespective of EU law, as a guide for the future. There followed a historical and comparative analysis and a consideration of the extent to which the most current animal welfare legislation takes account of the changing social construction of animals as sentient beings, using equines as a specific and detailed example.

The inclusion of sentience as an accepted concept in the explanatory notes to the AWA is a welcome step. That appears to be the extent to which the new social construction is acknowledged in legislation and by the courts enforcing the Act. There is the new Draft Animal Welfare (Sentencing and Recognition of Sentience) Bill 2017 which could place the concept of sentience firmly in the statute books, but its fate is far from certain at a time of political turmoil over Brexit more generally that is absolutely unprecedented in this country. Further, this study has concluded below, what the law is enacted to say is only part of the problem.

The sentencing guidelines in animal cruelty cases post-date the Lisbon Treaty and there is ample scope therefore for these to give effect to Article 13. However, on the face of it they are unduly lenient if one is dealing with a sentient being as a victim. They do not even seem to accord with the severity found under the old PAA 1911, much less chime with the approach of other jurisdictions. There is little cohesion or symmetry in the arrangements for prosecutions to be brought either, given that there is no statutory body to enforce the Act. Further, there are a number of serious ambiguities in the legislation as drafted that hinder the protection of animal welfare. Chief among those is the absence of a clear duty of care and a test

142 'Brexit: "Tired" Public Needs a Decision, Says Theresa May' (BBC News Online, 2019) <https://www.bbc.co.uk/news/uk-politics-47647515> accessed 21 March 2019. 
for it together with a lack of certainty around how repeat offenders would be managed. Instead the legislation owes more to a social construction of animals as property, placing usefulness at a premium at that.

Equines are at particular risk because of the paucity of regulation surrounding commercial boarding at livery when compared to the stringent controls on catteries and kennels. Furthermore, the chances of a member of the public noticing a welfare transgression or a defiance of a DOO in a rural area are much lower than in a densely populated urban area where companion animals are more likely to be found. Finally, the lack of public funding which still continues as we emerge from 'austerity' is likely to be compounded by Brexit itself so the voluntary sector will continue to bear the brunt of the cost. This is considerable when taking into consideration investigations, rescue, rehabilitation and prosecutions. Unfortunately, while not doubting the commitment and effort in the Third Sector, the actors there, such as the RSPCA, are woefully under-resourced as well.

To summarise the conclusions of this study then; there is now wide recognition of animal sentience both in the populations of England and Wales and abroad. There is not only scientific evidence on this but also acknowledgement by United Kingdom and other legislators of the importance of this term. In the AWA, this acknowledgement stopped short of being enshrined in statute. The law so far has therefore not gone far enough to reflect the enormous changes in the social construct of the animal since the nineteenth century. Commentators agree that language is vitally important for shaping public attitudes and a key chance was missed to have such an influence for the better in 2006. The Draft Bill is a welcome step but is at too early a stage, and the political landscape too uncertain, to herald this as some sort of new dawn yet.

There are failings in all three branches of government regarding animal welfare and the AWA; these may yet hinder the effectiveness of the new law if passed as well. In addition to the inadequate drafting of the Act there is a failure in enforcement, with only $17 \%$ of authorities having inspectors to deal with animal welfare cases on a daily basis. ${ }^{143}$ Courts have also failed to find an adequate interpretation of the duties imposed in the Act on those people performing animal husbandry. There are various methods of statutory interpretation which have been used to address poor legislative drafting in other criminal provisions, but no such effort has been made to acknowledge the animal as a sentient being by doing so in relation to the AWA.

143 Cooke and others (n 101).

'Animal Welfare in England: Domestic Pets' (gov.uk, 2016) <https://www.publications. parliament.uk/pa/cm201617/cmselect/cmenvfru/117/11709.htm> accessed 11 March 2017. 
For most, individuals choose to take on a position of responsibility when caring for an animal; it is a position of trust and an obligation. For others, '... a good law, in the end, becomes an educational device, which, if it works properly, eventually vitiates the need for its own existence by creating a new culture in the regulated population'. ${ }^{144}$ The problem is the AWA is not good law, it fails to recognise the animal as a sentient being, other than paying 'lip service' to the idea It fails to create or encourage a new type of property, 'living property', which would place animals in a new category, enhance their welfare protection and help to educate those in society that are not yet alive to the new social construction of animals.

In short, based on the findings of this study and paper, Mr Gove may find the trust he seeks in short supply. As this paper has demonstrated, the problem does not lie just with Parliamentary drafting. As yet there is still time for a start to be made with new legislation post-Brexit. That, as things stand, may be a long way off though.

There is a wider moral issue, however, consider the refugee crises, the widening of the gap between the rich and the poor and the ever-depleting resources given out for human health and welfare by government. Western society needs to look hard at how it protects the 'vulnerable and voiceless' of all species. After all, Ghandi was clear that the greatness of a nation and its moral progress could be judged by the way its animals are treated. ${ }^{145}$

\footnotetext{
144 Bernard Rollin and Michael Rollin, 'Dogmaticisms and Catechisms: Ethics and Companion Animals' in Susan Armstrong and Richard Botzler (eds), The Animal Ethics Reader ( $2^{\text {nd }}$ edn, Routledge 2008) 550.

145 Widely attributed to Mahatma Gandhi.
} 